\title{
Primary CNS Lymphoma in Immunocompetent: A Review of Literature and Our Experience from Kashmir
}

\author{
Bă̆ışıklık Sistemi Normal Olan Olgularda Primer Santral Sinir Sistemi \\ Lenfoması: Literatür Incelemesi ve Keşmir Deneyimi
}

\author{
Rumana MAKHDOOMI ${ }^{1}$, Khursheed NAYIL ${ }^{2}$, Ahmad RAYEES ${ }^{1}$, Altaf KIRMANI ${ }^{2}$, Altaf RAMZAN², \\ Muhammad Baba KHALIL ${ }^{1}$, Anil DHAR ${ }^{2}$, Syed BESINA ${ }^{1}$, Nasima CHANDA ${ }^{1}$, Abdul Rashid LONE ${ }^{3}$, \\ Sumaira QADIRI ${ }^{1}$, Muhammad MAQBOOL ${ }^{4}$ \\ ${ }^{1}$ Department of Pathology, SKIMS, Kashmir, 190011, India \\ ${ }^{2}$ Department of Neurosurgery, SKIMS, Kashmir, 190011, India \\ ${ }^{3}$ Department of Medical Oncology, SKIMS, Kashmir, 190011, India \\ ${ }^{4}$ Department of Radiotherapy, SKIMS, Kashmir, 190011, India
}

Correspondence address: Rumana MAKHDOOMI / E-mail: rumanahamid@rediffmail.com

\begin{abstract}
AIM: To study the clinicopathological aspects of primary CNS lymphoma in immunocompetent patients.

MATERIAL and METHODS: Sixteen patients with primary CNS lymphoma were analyzed for their clinico-pathological characteristics and followed-up for the treatment and subsequent management in Neurosurgery, and Medical and Radiation Oncology.

RESULTS: The fronto-parietal region was the commonest location of CNS lymphoma; four cases of cerebellar lymphoma were seen. Our patients were relatively young with a mean age of 48 years and an age range of 35-60 years. Females outnumbered males with a ratio of 2.7:1. The commonest presentation was focal neurological-deficits and features of raised intracranial pressure. All the patients histologically had diffuse large B-cell lymphoma. Radiologically, most presented as disc-enhancing lesions. Two patients had multiple lesions. Most of the patients (10) died within a mean of 4.4 months (range 2 weeks-16 months).
\end{abstract}

CONCLUSION: Primary CNS lymphoma is seen in immunocompetent patients as well. Relapse is common after treatment and the overall prognosis is unfavorable.

KEYWORDS: Primary CNS lymphoma, Immunocompetent, Brain tumor

öz

AMAÇ: Bağışıklık sisteminde baskılanma olmayan primer santral sinir sistemi lenfomalı hastaların klinikopatolojik özellikleri.

YÖNTEM ve GEREÇ: Primer santral sinir sistemi lenfoması olan 16 hastanın klinikopatolojik özellikleri incelendi ve hastalar beyin cerrahisi, medikal onkoloji ve radyasyon onkolojisi bölümlerinde tedavi ve takip edildi.

BULGULAR: Bu seride lenfomanın sıklıkla frontoparietal bölgeye yerleştiği görüldü. Dört vakaya serebellar lenfoma tanısı konuldu. Bizim hastalarımız görece olarak genç yaştaydılar, ortalama yaş 48, yaş aralığı 35-60. Kadın hastalar çoğunluktaydı, kadın/erkek oranı 2.7/1 olara belirlendi. En sık görülen belirti fokal nörolojik defisit ve kafa içi basınç artışına bağlı bulgulardı. Tüm hastaların histolojik tanısı yaygın geniş $B$ hücreli lenfomaydı. MRG'de en sık karşılaşılan lezyon şekli oval görünümlü kontrast tutulumu olan lezyonlardı, iki hastada ise çoklu lezyonlar vardı.

SONUÇ: Primer santral sinir sistemi lenfoması bağışıklık sisteminde baskılanma olmayan insanlarda da görülmektedir. Hastalık tedaviye rağmen tekrarlamakta ve hastalığın genel prognozu kötü olarak seyretmektedir.

ANAHTAR SÖZCÜKLER: Primer santral sinir sistemi lenfoması, Yeterli bağışıklık, Beyin Tümörü

\section{INTRODUCTION}

Primary CNS lymphoma (PCNSL), a rare form of extranodal non-Hodgkin's lymphoma, occurs in the brain, leptomeninges, spinal cord, or eyes, and typically remains confined to the
CNS. PCNSL in immunocompetent patients is associated with unique diagnostic, prognostic and therapeutic issues (4). The incidence of primary CNS lymphomas is increasing not only in patients with AIDS, but also in the non-AIDS population (17). In the non-AIDS group, the rise in CNS 
lymphomas has outstripped the general rise in systemic hematopoietic malignancy. In the West, the increase in the incidence of primary CNS lymphoma is attributed to the AIDS epidemic and most cases of PCNSL are seen in patients with immunodeficiency $(6,15)$. However, primary CNS lymphomas are seen commonly in immunocompetent patients in India as has been reported in major series $(25,32,33,37)$. We hereby analyze 16 cases of non-Hodgkin's lymphoma for their clinical features, radiological features, their histology, management and outcome.

\section{MATERIAL and METHODS}

This study was carried out at the Sher-i-Kashmir Institute of Medical Sciences (SKIMS), Soura, which is a 750-bed tertiary care centre.

All cases of primary CNS lymphoma diagnosed in the Department of Pathology from 2006 to 2009 were included in the study. The cases were analyzed for age, sex, clinical presentation and laboratory features. Details about lymphadenopathy, organomegaly and bone marrow study were obtained to exclude the possibility of secondary involvement by a systemic lymphoma. Besides the routine hematoxylin and eosin stains (H\&E) and special stains, PTAH (phospho-tungistic acid and hematoxylin), reticulin stain, and immunohistochemistry was performed using CD-45 CD-20, CD-19 , CD-3, CD-5, antibodies for typing of these lymphomas. CD-10,MIB-I,BCl-6 were also used for some cases. Nineteen cases of primary CNS lymphoma were diagnosed in the 3-year period and 3 cases were excluded from the study as they contained inadequate material for further evaluation. All cases were analyzed for imaging features and followed up for management in Neurosurgery, Radiation and Medical
Oncology. Eastern Cooperative Oncology Group (ECOG) performance status was used to assess the clinical status of patients in outpatient departments on follow-up, wherein ECOG of 0 was accepted as fully active and able to carry on all pre-disease performance without restriction and ECOG of 5 was accepted as dead (31).

\section{OBSERVATIONS}

\section{Demography}

The age range was 35 to 60 years and the mean age was 48 years. The commonest age group involved was 50-60 years. The youngest patient was a 35-year-old male. There were 11 females (69\%) and 5 males (31\%).

\section{Clinical Symptoms/Laboratory parameters}

The mode of presentation in decreasing order was raised ICP $(50 \%)$, hemiparesis only $(25 \%)$, seizures only $(6.25 \%)$, seizures and hemiparesis (6.25\%), raised ICP and hemiparesis (6.25\%) and gait ataxia (6.25\%). The symptom duration varied from 2 days to 3 months (Table I) Hemogram and routine tests (i.e) liver function, kidney function tests were normal. All patients were HIV negative. Serum LDH levels were available in 6 patients and were raised in 4 patients.

\section{Imaging features}

A CT scan was available in all the patients and MRI in 9 patients. There were total 18 lesions in 16 patients. On plain CT scan, 13 lesions were hyperdense, 4 were isodense and one lesion was hypodense. All the lesions showed moderate enhancement on contrast CT scan. 12 lesions had disc enhancement and ring enhancement was noticed in 5 lesions. Lesions were single in 14 patients and multiple in 2 patients. Apoptotic
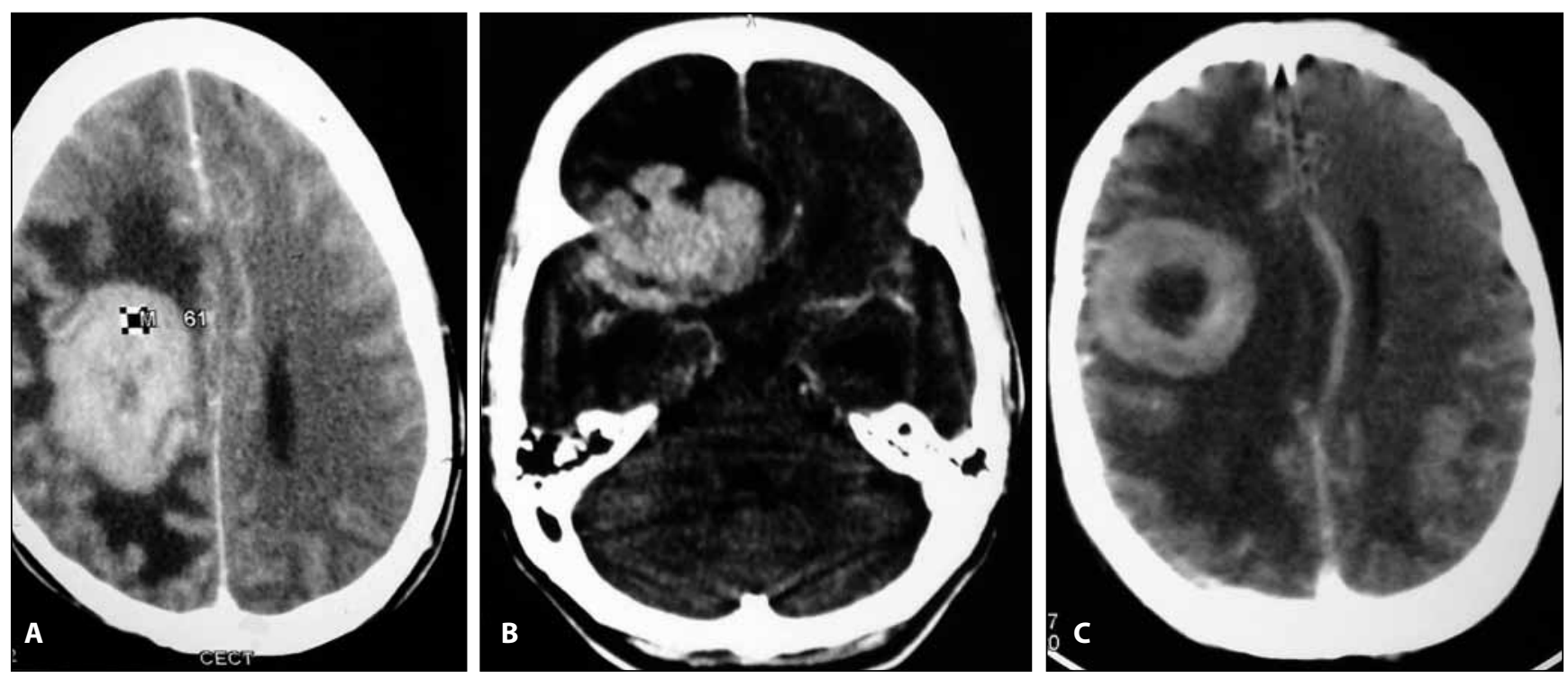

Figure 1: A) Contrast enhanced CT scan axial section shows an enhancing mass in right mid 1/3rd parasagittal area of brain (Case 7 ). B) Contrast enhanced CT scan axial section show a lobulated intensely enhancing mass along the right sphenoid ridge, which preoperatively was thought to be a meningioma (Case 5 ). C) Contrast enhanced CT scan axial section show an enhancing lesion in right frontal area with central necrosis(apoptotic steroid effect). 
steroid effect was seen on CT scans of one patient who after diagnosis of a mass lesion at a local hospital was started on steroids (Figure 1C).

The commonest site of the lesion was frontal and frontoparietal lobes (50\%) followed by the cerebellum (25\%). MRI scans in 9 patients revealed the lesions to be hypointense on T1W and iso- to hyperintense on T2-weighted images. All the lesions were associated with perilesional edema as noticed on FLAIR sequences. All the lesions showed marked enhancement on MRI (Figure 2). Enhancement on MRI along the Virchow-Robin space was not seen in any of our patients. None of the lesions on imaging had evidence of bleed or calcification and only 1 patient had a lesion with a central necrosis. MRS was done in 5 patients only and it revealed Choline peaks in all the lesions. One case showed leptomeningeal enhancement but subependymal infiltration was not seen in any case.

Preoperative diagnosis was lymphoma in 9 patients, meningioma in 2, glioma in 2, abscess in 2 and metastasis in one. Out of the 9 patients in whom a preoperative diagnosis of lymphoma was made on imaging, 4 underwent stereotactic biopsy and confirmation while 5 underwent open surgery and confirmation of the diagnosis as these 5 patients had raised ICP features. Out of a total of 18 lesions in 16 patients, eleven lesions were seen on the left side, 6 on the right side and 1 lesion was involving the splenium with biparietal extension.

\section{Intervention}

Craniotomy and decompression of the lesion was performed in 12 patients and stereotactic biopsy was performed in 2 thalamic lesions, in 1 basal ganglia lesion and 1 lesion involving the splenium. Craniotomy and decompression were used in patients with lobar or cerebellar involvement.

\section{Intraoperative features}

Most lesions were firm, could be partly aspirated and moderately vascular. Four cases were diffusely infiltrating without demarcation from the surrounding brain. Others showed a clear-cut demarcation from the surrounding brain parenchyma. The dura was normal in all the patients, and there was no gross evidence of its involvement. Intraoperative diagnosis of a lymphoma/small round cell tumor on crush biopsy was made in 12 cases. In 2 cases the diagnosis of glioblastoma multiforme was made, in one case diagnosis was metastasis whereas one crush biopsy specimen showed only necrosis.

\section{Microscopic features}

Histopathology showed most cases depicted a monomorphic population of lymphoid cells with areas of necrosis. The characteristic angiocentric pattern was seen in most cases (12 cases) (Figure 3A,B). Individual cells were large with prominent nuclei. On H\&E 12 cases showed immunoblastic morphology with few interspersed centrocytes. One case showed large cells which on crush was thought to be a metastatic carcinoma but Alk-1 and Cytokeratin were negative. Reticulin preparation showed concentric reticulin fibers around blood vessels. One

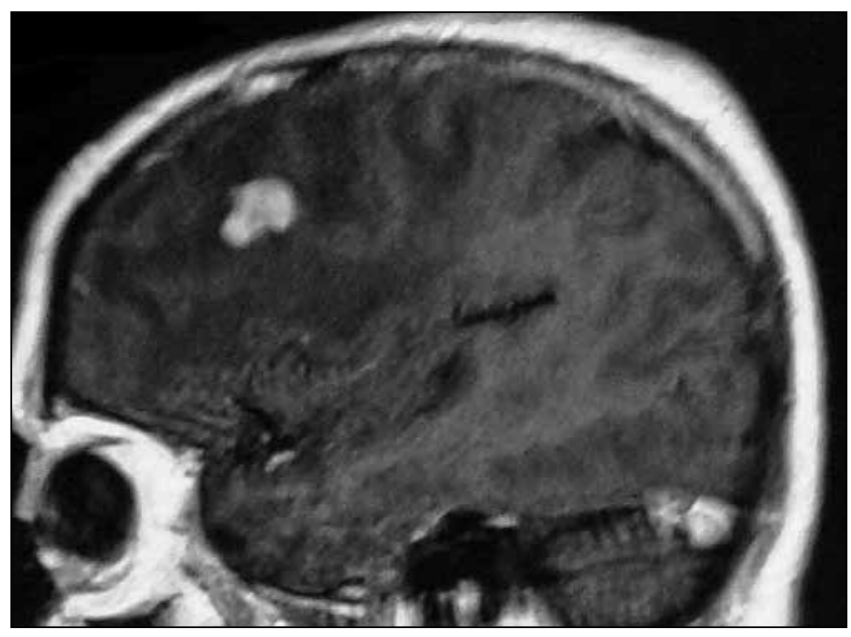

Figure 2: Contrast MRI sagittal sections show a homogenously enhancing frontal lesion with perilesional edema.

case showed a mixed infiltrate and on histology was thought to be a T-cell lymphoma, however immunostaining revealed it as a B-cell lymphoma with infiltrating $T$ cells. Yet another case showed a starry sky appearance because of the presence of tingible body macrophages, giving rise to starry sky appearance (Figure 3C), but MIB-1 labeling index was low. All cases showed a diffuse growth pattern, with patchy necrosis.

\section{Immunohistochemical profile}

All cases were positive for CD-45, CD-19 and CD-20 (Figure $4 A, B)$. CD-20 positivity was noted with weak CD-3 and CD-5 positivity in two B cell lymphomas (Figure 4C). Bcl-6, Ki67 was used for the case which was thought to be Burkitt's lymphoma. Alk-1 was used for the patient in whom the possibility of anaplastic large cell lymphoma was considered.

\section{Adjuvant therapy}

All the patients were subjected to radio-chemotherapy after surgical decompression/stereotactic biopsy and histopathological/ immunohistochemical diagnosis of lymphoma.

Depending on the treatment modalities applied, patients after surgery were categorized into:

1. Those who were treated with chemotherapy only.

2. Those who were treated by combined radiotherapy and chemotherapy.

3. Those who received supportive therapy only because of severe neurological deficits/poor clinical performance/ rapidly progressive disease /those in whom planned therapy could not be completed.

\section{Follow Up}

Follow up was done jointly in Tumor Clinic which is managed by the Departments of Neurosurgery, Radiation Oncology and Medical Oncology. Only 14 patients came for follow- 

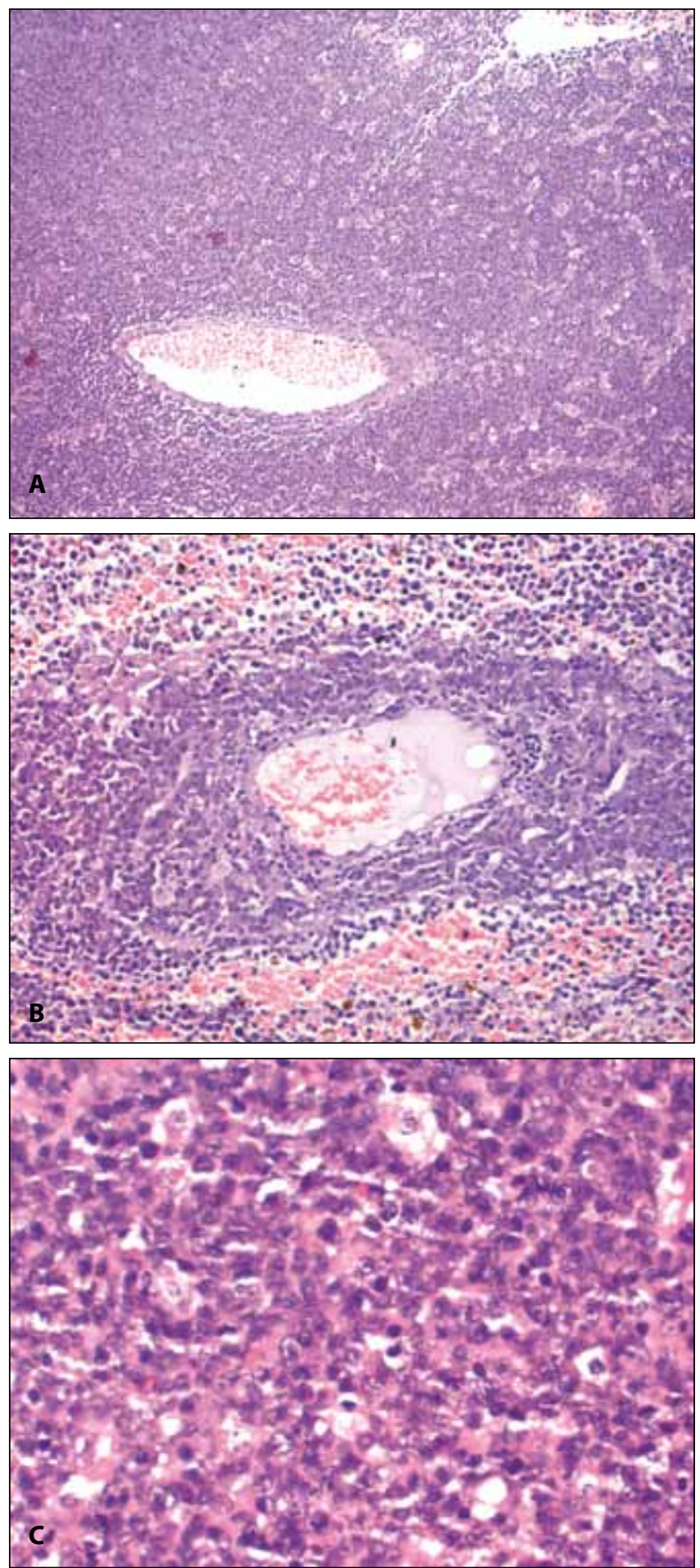

Figure 3: A) Photomicrograph showing neoplastic lymphoid cells around a vessel (H\&EX10). B) Photomicrograph showing neoplastic lymphoid cells around a vessel with hemorrhage and congestion (H\&EX20). C) Photomicrograph showing tumor cells with many tingible body macrophages (Burkitt-like morphology) H\&Ex40. up. The mean follow-up time was 9 months (range, 10-20 months).Outcome was analyzed by using Eastern Cooperative Oncology Group performance status (31).Ten patients died on follow-up i.e., had ECOG of 5; 3 patients were fully active, able to carry on all pre-disease performance without restriction
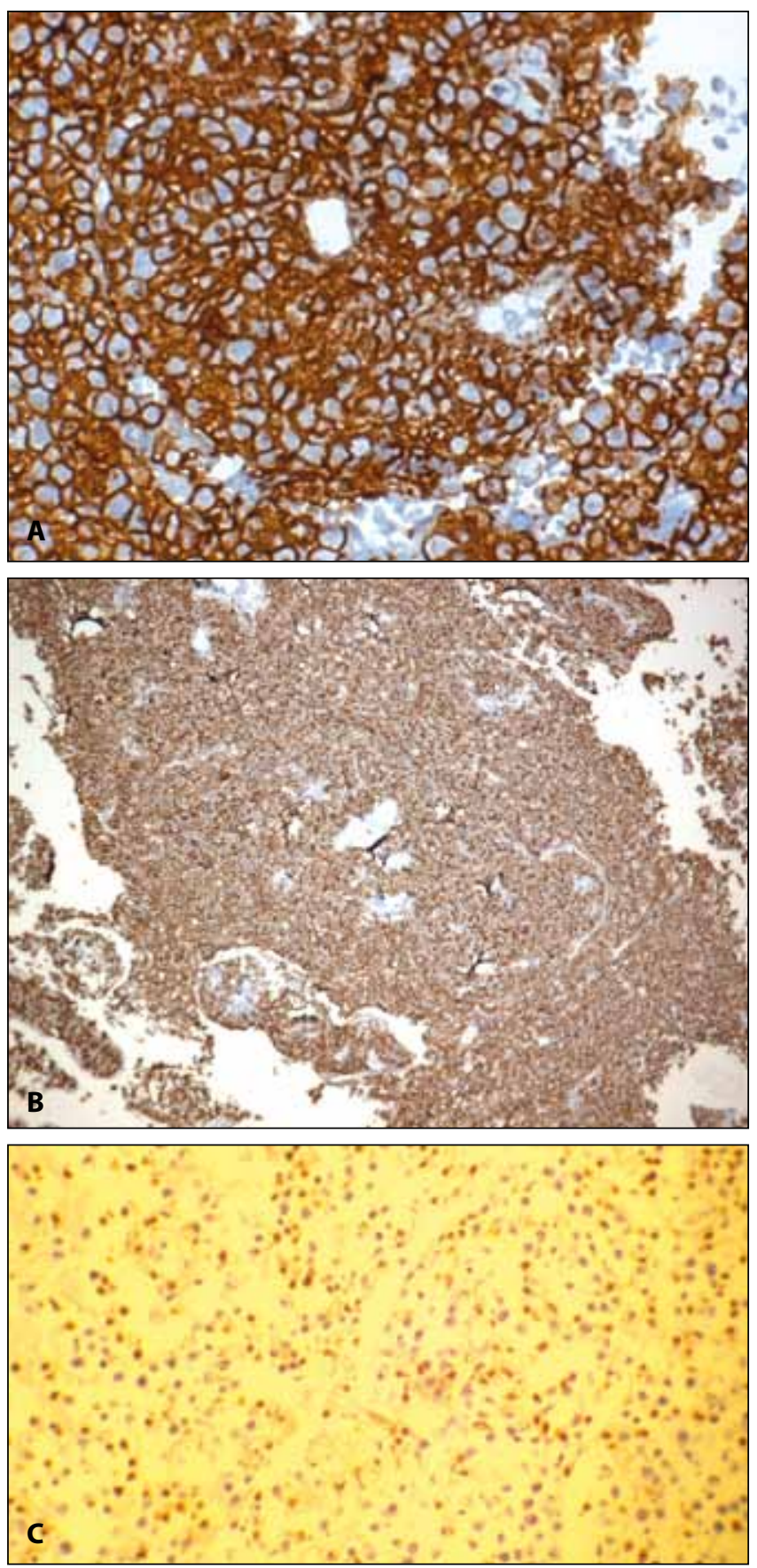

Figure 4: A) Photomicrograph showing tumor cells with strong LCA positivity (Immunostain x 40). B) Photomicrograph showing tumor cells with strong CD-20 positivity (Immunostain $\times 20$ ). C) Photomicrograph showing tumor cells with interspersed CD-3 positive cells (Immunostain $\times 20$ ). 
i.e., had ECOG of 0 ; and 1 patient was restricted in physically strenuous activity but ambulatory and able to carry out work of a light or sedentary nature i.e., had ECOG of 1.

\section{DISCUSSION}

Primary CNS lymphoma is a rare form of non-Hodgkin's lymphoma that occurs within the craniospinal axis and accounts for less than $5 \%$ of all primary brain tumors. It is defined as lymphoma occurring in the brain, leptomeninges, spinal cord or eyes without evidence of lymphoma outside the CNS (4). The majority of PCNSL tumors are high grade B-cell lymphomas, despite the fact that B-cells are absent from the normal brain $(4,16)$. During the past 30 years, the incidence of PCNSL has increased dramatically in all age groups (39). A primary factor responsible for the increase has been the human immunodeficiency virus epidemic (4). Patients with AIDS develop PCNSL at a rate 3600 -fold higher than the general population and have a lifetime risk of CNS lymphoma that approaches $20 \%$ (11). There has been an increasing incidence of disease among immunocompetent individuals which appears to be independent of overall trends in the incidence of brain tumors and NHL has outpaced the milder increase in systemic lymphomas and remains essentially unexplained (35). The reasons for this increase appear to be environmental factors unrelated to the heightened awareness or improved diagnostic modalities.

The Kashmir valley is distinct geographically and culturally from the rest of India (36) and the cancer pattern is also different from the rest of India. In our 3-year analysis, we encountered 16 patients of primary CNS lymphoma involving the brain and all patients were immunocompetent with normal CD-4 counts. Kashmir valley falls in a low prevalence zone for HIV (22). Studies on CNS lymphomas from other parts of India have shown that the majority of PCNSL's have been reported in immunocompetent persons $(25,32,33,37)$. Sarkar C et al. (37) had one HIV positive patient and 1 patient with a renal allograft in a series on CNS lymphomas. Powari et al. (33) had 2 patients with renal allografts. In spite of the increasing number of HIV positive patients elsewhere in India (23), the incidence of PCNSL's in these patients has not been found to be increased. A positive explanation for this could be that AIDS patients die earlier in India due to opportunistic infections (37).

The youngest patient in our study was a 35-year-old male. The mean age of the patients was 48 with a range of 35-60 years. Out of 16 cases, 5 were males and 11 females and the male to female ratio was 1:2.7. The female preponderance seen in our cases has not been noted in other series from India $(25,32,33,37)$. The female preponderance seen in one study needs to be evaluated further to know if hormones have a role to play in the causation of the PCNSL in Kashmiri females, making them susceptible to this tumor. The Kashmiri population is also a distinct ethnic population separated from the rest of the country by tough geographical barriers and needs to be seen in the light of a genetic predisposition of Kashmiri females to the etiological agent causing lymphoma.
Further studies are needed in this regard. In our series, the age of presentation is less than the usual age of presentation of PCNSL in immunocompetent persons. The highest risk group for patients with primary central nervous lymphoma is 60 years but the typical age at presentation is younger in patients with AIDS with the common age being 31 to 36 years $(6,20)$.

In a study on 9 patients by Mattei TA (27), $62.5 \%$ of patients in the study were females. In a study on 164 cases of primary CNS lymphoma in immunocompetent patients by Feuerhake $F(19)$, the mean age of patients was 61.7 years with a range of $28-84$ years. $54.3 \%$ of patients were males and $45.7 \%$ were females. The duration of symptoms varied from 2 days to 3 months.

In our analysis we looked back at our data available in the Department of Pathology and found that only 4 cases of PCNSL were diagnosed from 1982 to 2005. These cases had insufficient clinical data and could not be included in the present series. On comparative analysis, 16 cases in a 3-year period indicate improved diagnostic measures and also point out towards an increased frequency of PCNSL in immunocompetent persons which is a reflection of an overall increase in PCNSL frequency as noted globally.

The most common presentation was headache and vomiting, seen in 8 patients ( $50 \%)$. This was followed by focal neurological deficit in 6 patients $(37.5 \%)$. Two patients presented with seizures and one patient had gait ataxia. Patients with PCNSL present with neurological symptoms and signs rather than systemic ' $B$ ' symptoms such as fever, weight loss and night sweats (4). None of our patients presented with B symptoms. In a study on clinical presentations of 248 immunocompetent patients with PCNSL, the authors reported $70 \%$ of the patients had focal neurological deficits, $43 \%$ neuropsychiatric symptoms, $33 \%$ increased intracranial pressure, $14 \%$ seizures and $4 \%$ ocular symptoms (3). Some studies have reported disturbance of intellectual functions and behavior problems as the commonest symptoms in supratentorial PCNSL's (24).

Focal motor or sensory neurological deficits have been noted by Feuerhake $\mathrm{F}$ as the commonest symptoms of PCNSL in his series (19). Eichler FA (16) noted focal neurological deficits in $70 \%$ of immunocompetent patients with PCNSL. Generalized seizures were relatively rare as an initial presenting symptom as in our study where only 2 patients presented with seizures. Multiple lesions were seen in 2 cases. Eight of our patients had the tumor localized to the frontal or frontoparietal lobe and 4 patients had the tumor localized to the cerebellum. Most of the lesions were on left side (Table I). The literature reports the frontal and parietal lobes as the most common site of involvement $(9,27)$. PCNSL lesions are primarily located in periventricular areas involving the thalamus, basal ganglia and corpus callosum in $60 \%$ of the cases. The cerebral lobes are involved in the following frequency of order: frontal lobe $20 \%$, parietal lobe $18 \%$, temporal lobe $15 \%$ and occipital lobe $4 \%$ (2). We also noticed the frontal lobe to be a favorite site. Four cases of cerebellar lymphoma were seen, of which one was multicentric. The cerebellar lymphomas had a male to 
:

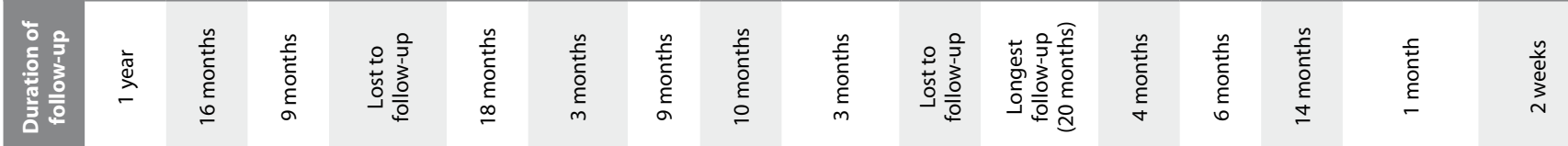

I.

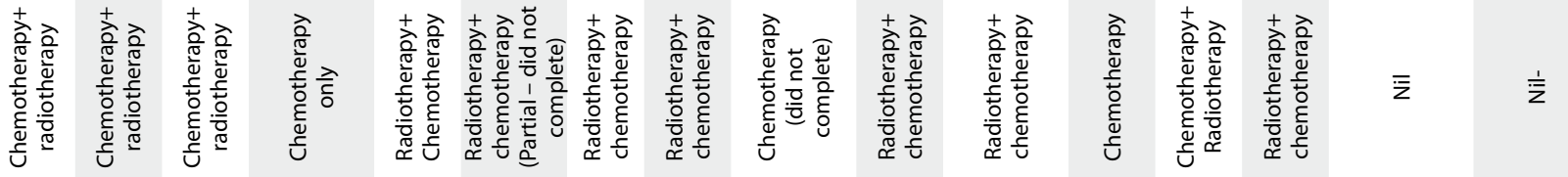

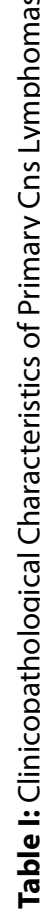

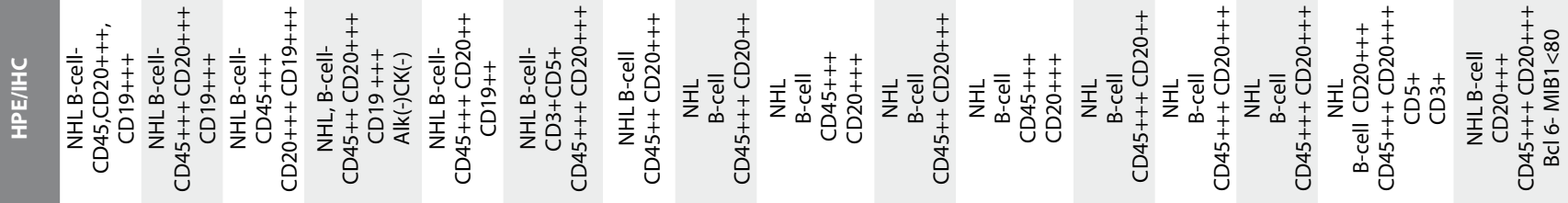

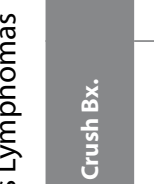

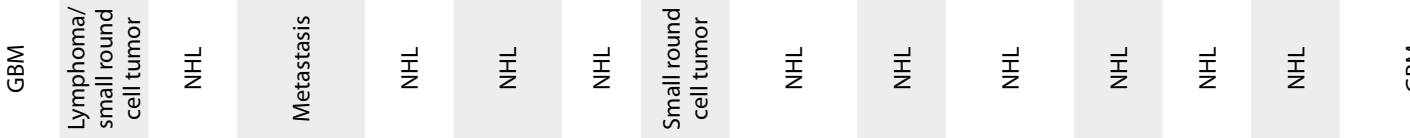

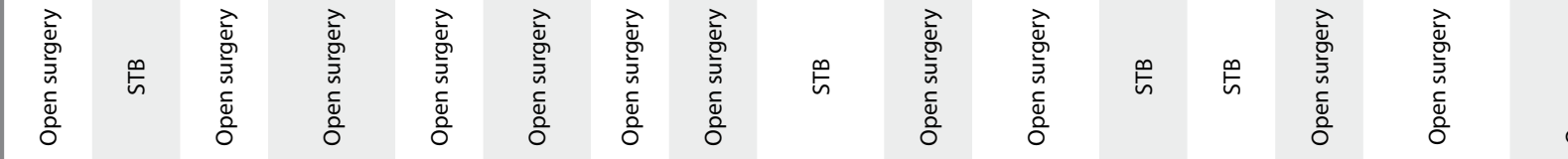

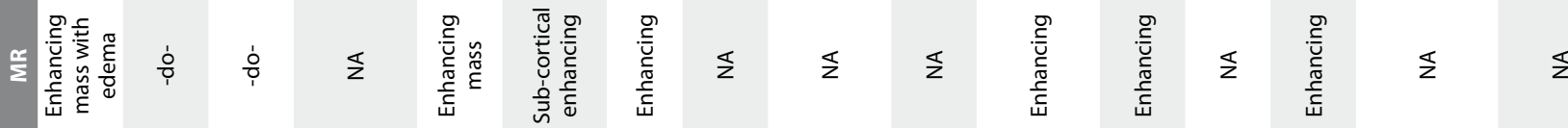

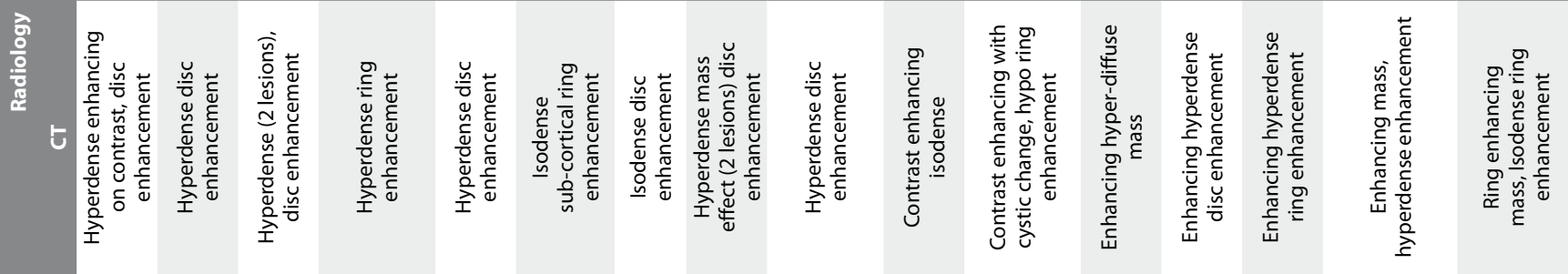

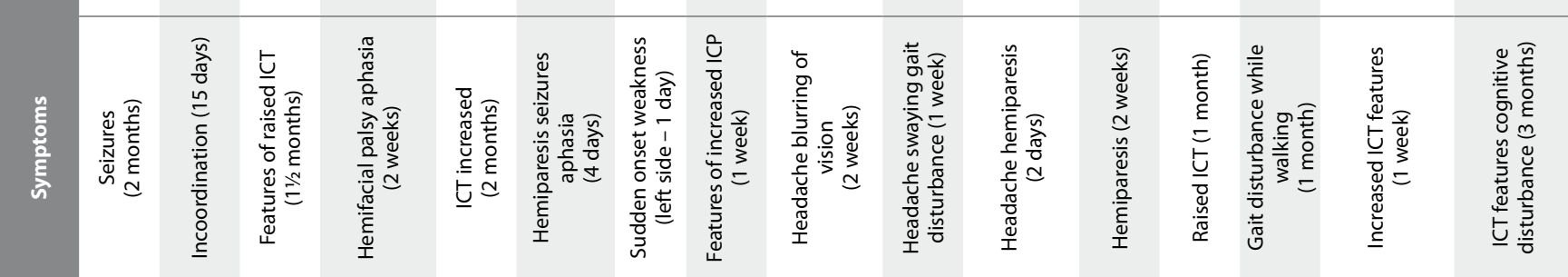

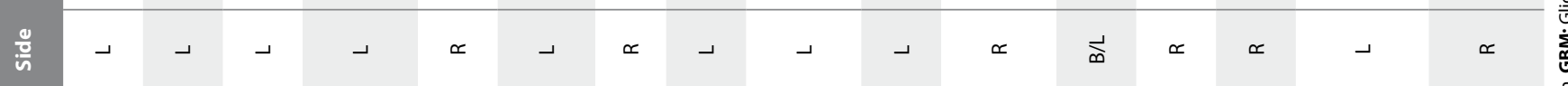

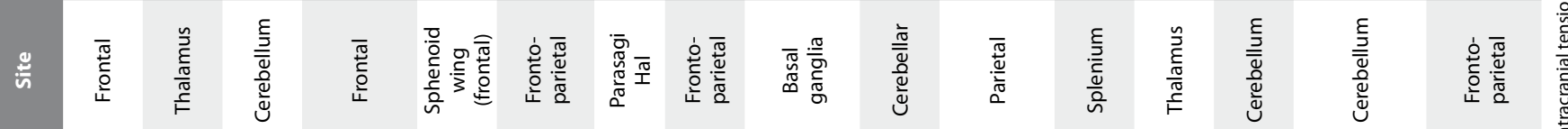

\begin{tabular}{|c|c|c|c|c|c|c|c|c|c|c|c|c|c|c|c|}
\hline 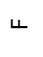 & น & 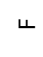 & ч & ч & ч & $\Sigma$ & 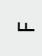 & \llcorner & 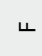 & $\Sigma$ & $\Sigma$ & 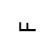 & $\Sigma$ & ч & $\Sigma$ \\
\hline in & ஜ & 8 & in & in & q & $\stackrel{\infty}{+}$ & in & q & ஜ & $\stackrel{m}{m}$ & 8 & in & q & 8 & ஜ \\
\hline- & $\sim$ & $m$ & $\sigma$ & in & 0 & n & $\infty$ & $a$ & $\circ$ & $=$ & $\simeq$ & $\stackrel{m}{n}$ & \pm & $\stackrel{n}{\sim}$ & $\stackrel{\circ}{\circ}$ \\
\hline
\end{tabular}


female ratio of 1:1 and two had a short survival. One patient with cerebellar lymphoma succumbed to the disease within 1 month of surgery.

Primary central nervous system lymphoma has a characteristic appearance on both CT and MR imaging studies (12). The masses most commonly appear isodense on hyperdense on $\mathrm{CT}$ scans and enhance on contrast. On MR imaging, most lesions are hypointense to gray matter on T1-weighted images, iso-or hyperintense on T2-weighted images and enhance moderately to markedly after contrast administration (16). Linear enhancement at the margins of a lesion, tracking along the Virchow-Robin perivascular spaces, is highly specific for PCNSL (37). A higher T2 signal is often seen surrounding the lesion and extending along adjacent white matter tracts, representing tumor-associated vasogenic edema. Lesions may appear hyperintense on diffusion weighted images and apparent diffusion coefficient maps because of the relative restriction of water diffusion within PCNSL, a characteristic shared by acute ischemic strokes, cerebral abscess and several other high grade neoplasms. Evidence of hemorrhage, calcification or necrosis within a PCNSL lesion may be seen, but is rare before treatment (16).

In our series on preoperative imaging, we made a diagnosis of lymphoma in 9 patients, meningioma in 2, glioma in 2, abscess in 2 and metastasis in one. Frontal lymphoma simulated a meningioma on imaging in one patient. We had two patients with multiple lesions though multiple lesions are rare in immunocompetent patients with PCNSL's and are often seen in patients with HIV $(3,15)$.

Brain biopsy remains the gold standard for diagnosing PCNSL (16). A diagnostic pitfall in the evaluation of brain biopsies (2) for lymphoma occurs when the patient has received steroids prior to the biopsy. Steroids induce apoptosis of lymphoid cells and can deplete the brain tissue of neoplastic infiltrates within 24-48 hrs, leaving behind a milieu of gliosis and relatively few reactive lymphocytes and/or macrophages. With time however, the lymphoma becomes resistant to steroid treatment possibly through selective growth of clones exhibiting steroid receptor deficiency or through a postreceptor defect in apoptotic pathways (19).

Out of 16 cases, 15 were B-cell lymphomas, all exhibiting an angiocentric pattern on histology with positivity for CD-20 and CD-19. One patient demonstrated an atypical starry sky appearance with many tingible body macrophages but did not stain for Bcl-6 and MIB-1 was low. The patient succumbed to the disease within 2 weeks of diagnosis. One case of cerebellar lymphoma showed a polymorphic lymphocytic infiltrate and on immunohistochemistry was positive for CD-20 and weakly positive for CD3 and CD5. This lymphoma showed an aggressive clinical course and the patient succumbed to the disease within 1 month of surgery. T-cell lymphoma arising from the cerebellum has been reported $(14,38)$. The prognosis of these tumors remains unfavorable despite their sensitivity to irradiation and chemotherapy (24).
PCNSL is a form of extra-nodal non-Hodgkin's lymphoma and is classified as stage IE disease according to the Ann Arbor staging system where stage I represents localized lymphoma and $E$ denotes extranodal disease. However, the prognostic significance of the Ann Arbor staging system does not apply to PCNSL (4). The International Extranodal Lymphoma Study Group reported that the following parameters were associated with poor prognosis: age older than 60 years, performance status greater than 1 on the Eastern Cooperative Oncology Group performance status scale; elevated serum LDH; high CSF protein concentration and tumor location within the deep regions of the brain, i.e., the periventricular regions, basal ganglia, brainstem and/or cerebellum (18). Miller, in a study on 104 patients, studied recurrence patterns in 64 patients and PCNSL recurred either at the original site or elsewhere in the neuraxis in 52 patients (28). Many authors have worked out many histological features, i.e., apoptosis, vascularity and proliferation, to have a relationship with tumor aggressiveness but most have not found a statistically significant correlation with survival (35).

PCNSL is highly radiosensitive. Median survival improves with radiotherapy (21). The optimal dose of radiation is controversial but the Radiation Therapy Oncology Group concluded that a dose of 40-Gy to the whole brain and 20-Gy boost dose to the tumor and its margin should be administered. Spinal irradiation is indicated if cerebrospinal fluid cytology suggests spinal dissemination (30).

Whole brain radiotherapy, the standard therapy for PCNSL for many years has largely been replaced by combination chemotherapy with high dose methotrexate and radiotherapy. Chemotherapy has a definite role. Patients who receive both radiotherapy and chemotherapy have longer survival(34). Chemotherapeutic agents often used are methotrexate, corticosteroids, vincristine and cyclophosphamide. Among these, methotrexate readily penetrates the blood brain barrier and has shown promising results $(7,13)$. The intrathecal route has provided the best results for methotrexate (26).

Chemotherapy should be given before radiotherapy. Advantages are that the side effects of methotrexate get ameliorated if it is given before radiotherapy (8). Younger age is associated with favorable survival (19). In our series, a 35-oldmale patient survived the longest ( 20 months). The prognosis for PCNSL is worse than for other extranodal lymphomas. Relapse occurs in almost all cases.. Ninety-percent of relapses occur within the brain. Treatment is primarily palliative (1). The overall prognosis of PCNSL. lymphoma in our patients was not good in spite of combined chemotherapy and radiotherapy. The longest follow-up was 20 months in a 35-year-old male.

PCNSL is an enigmatic disease of uncertain origin (18). The association of Epstein Barr virus with PCNS lymphoma in patients with HIV is well known but its association in patients without HIV infection is not documented (10). It is not known whether the relationship between EBV and human lymphoma is causal or purely coincidental (29). 
Genetic studies, viral studies and other molecular studies are required to find the nature of occurrence of PCNSL in the Kashmiri population. Primary CNS lymphoma is more frequently diagnosed in this population and all cases reported are immunocompetent. In the West, there is an increase in the frequency of PCNSL in immunocompromised and immunocompetent persons but these have not surpassed the glial tumors as the most frequently diagnosed brain tumors (5).

\section{CONCLUSION}

The distinctive features of our study were:

1. Primary CNS lymphoma was seen in immunocompetent persons. None of our patients was immunocompromised or HIV positive.

2. PCNSL was common in females.

3. The age of presentation was relatively younger age with a mean age at presentation of 48 years.

4. The fronto-parietal region was the commonest site involved and the cerebellum was not an infrequent site of involvement.

5. Raised ICP features and focal neurological deficits were the commonest clinical presentations.

\section{REFERENCES}

1. Amin-Hanjani S, Griffith RH IV: Cerebral lymphoma;in Youmans Neurological Surgery, 5th ed. Saunders, 2004:1067-1076

2. Antinori A, Ammassari A, De Luca A, Cingolani A, Murri R, Scoppettuolo G, Fortini M, Tartaglione T, Larocca LM, Zannoni G, Cattani P, Grillo R, Roselli R, Jacoangeli M, Secrrati M, Ortona L:Diagnosis of AIDS-related focal brain lesions; a decision making analysis based on clinical and neuroradiologic characteristics combined with polymerase chain reaction assays in CSF. Neurology 48(3): 687-694,1997

3. Bataille $B$, Delwail V, Menet E, Vandermarcq $P$, Ingrand $P$, Wager $M$, Guy G, Lapierre F: Primary intracerebral malignant lymphoma: Report of 248 cases. J Neurosurg 92(2):261-266, 2000

4. Batchelor T, Leoffler JS: Primary CNS lymphoma. J Clin Oncol 24(8):1281-1288, 2006

5. Benjamin WC, Marcus SM, Allan Topham, Hauck W, Walter J, Curran Jr: Will primary central nervous system lymphoma be the most frequent brain tumour diagnosed in the year 2000? Cancer 12:2409-2413,1997

6. Bhagavathi S, Wilson JD. Primary central nervous system lymphoma. Arch Pathol Lab Med 132(11):1830-1834,2009

7. Blay J-Y, Conroy T, Chevreau C, Thyss A, Quesnel N, Eghbali $\mathrm{H}$ :High-dose methotrexate for the treatment of primary cerebral lymphomas: An analysis of survival and late neurological toxicity in a retrospective series. J Clin Oncol 16:864-871,1998

8. Bleyer WA:Neurological sequelae of methotrexate and ionizing radiation: A new classification. Cancer Treat Rep 65:89-98,1981

9. Camilleri-Broet $S$, Martin A, Moreau A, Angomin R, Henin D, Gontier MF, Rousselet MC, Caulet Maugendre S, Cuilliere $P$, Lefrancq $T$, Mokhtari K, Morcos M, Broet P, Kujas M, Hauw JJ, Desablens B,
Raphael M: Primary central nervous system lymphomas in 72 immunocompetent patients pathologic findings and clinical correlations. Groupe Ouest Est D'etude des Leucenies et Autres Maladies du Sang (GOELAMS). Am J Clin Pathol 110(5):607-612, 1998

10. Kadoch C, Tresseler P, Rubenstein JL: Molecular pathogenesis of primary central nervous system lymphoma. Neurosurgery Focus 21(5):1,2006

11. Cote TR, Manns A, Hardy CR, Yhartge PFJ: Epidemiology of brain lymphoma among people with or without acquired immunodeficiency syndrome. AIDS/Cancer Study Group. J Natl Cancer Inst 88(10):675-679, 1996

12. Coulon A, Lafitte F, Loang-Xuan K, Martin-Duverneuil N, Mokhtari $\mathrm{K}$, Blustajn J, Chiras J: Radiographic findings in 37 cases of primary CNS lymphoma in immunocompetent patients. Eur Radiol 12(2):329-340,2002

13. De Angelis LM, Yahalom J, Thaler HT, Kher U: Combined modality therapy for primary CNS lymphoma. J Clin Oncol 10:635-643,1992

14. Dulai MS, Park CY, Howell WD, Smyth LT, Desai M, Carter DM, Vogel H: CNS T-cell lymphoma: An under-recognized entity? Acta Neuropathol 115(3):345-356,2008

15. Eby NL, Grufferman S, Flannelly CM, Schold SC Jr, Vogen FS, Burger PC: Increasing incidence of primary brain lymphoma in the US. Cancer 62(11):2461-2465,1988

16. Eichler AF, Batchelor TT: Primary central nervous system lymphoma: Presentation, diagnosis and staging. Neurosurg Focus 21(5):E15,2006

17. Elizabeth AM, Fine HA: Primary CNS lymphoma. Semin Oncol 26:346-356,1999

18. Ferreri AJ, Blay JY, Reni $M$, Pasini $P$, Spina $M$, Ambrosetti $A$ Calderoni A, Rossi A, Vavassori V, Conconi A, Devizzi L, Berger $F$, Ponzoni $M$, Borisch $B$, Tinguely $M$, Cerati $M$, Milani $M$, Orvieto $E$, Sanchez J, Chevreau C, Dell'Oro S, Zucca E, Cavalli P: Prognostic scoring system for primary CNS lymphomas: The International Extranodal Lymphoma Study Group experience. J Clin Oncol 21(2):266-272, 2003

19. Feuerhake F, Baumer C, Cyron D, Illerhaus G, Olschewski $M$, Tilgner J, Ostertag CB, Volk B: Primary CNS lymphoma in immunocompetent patients from 1989 to 2001: A retrospective analysis of 164 cases uniformly diagnosed by stereotactic biopsy. Acta Neurochir (Wien) 148(8):831-838, 2006

20. Fine HA, Mayer RJ: Primary central nervous system lymphoma. Ann Intern Med 119(11):1093-1094, 1993

21. Hayakawa T, Takakura K, Abe et al: Primary central nervous system lymphoma in Japan: A retrospective, co-operative study by CNS-lymphoma Study Group in Japan. J Neurooncol 19:197215,1994

22. http://www.risingkashmir.com/index. Accessed on 15-11-2009

23. http://www.nacoonline.org accessed on 3.2.2010.

24. Jiddane M, Nicoli F, Diaz P, Bergvall U, Vincentelli F, Hassoun J, Salamon G: Intracranial malignant lymphoma. Report of 30 cases and review of the literature. J Neurosurg 65(5):592-599,1986

25. Kumari N, Krishanani N, Rawat A, Agarwal V, Lal P: Primary central nervous system lymphoma in Northern India. Surg Neurol 57(2):113-116,2002

26. Liang $B C$, Grant R, Junck L: Primary central nervous system lymphoma: Treatment with multiagent systemic and intrathecal chemotherapy with radiation therapy. Int J Oncol 3: 10011004,1993 
27. Mattei TA, Mattei IA, Aguiar DH, Ramina R: Primary central nervous lymphomas in immunocompetent patients. Neurochiruga 17: 46-53,2006

28. Miller DC, Hochber FH, Harris NL, Gruber ML, Louis DN, Cohen $\mathrm{H}$ : Pathology with clinical correlations of primary central nervous system non-Hodgkin's lymphoma. The Massachusett's General Hospital experience 1958-1989. Cancer 74(4):1383-1397, 1994

29. Morgello S: Epstein-Barr and human immunodeficiency viruses in acquired immunodeficiency syndrome-related primary central nervous system lymphoma. Am J Pathol 141(2):441-450,1992

30. Nelson DF, Martz KL, Bonner H et al: Non-Hodgkin's lymphoma of the brain: Can high dose, large volume radiation therapy improve survival? Report on a prospective trial by the Radiation Therapy Oncology Group (RTOG):RTOG 8315. Int J Radiat Oncol Biol Phys 23:9-17,1992

31. Oken MM, Creech RH, Tormey DC, Horton J,Davis TE, McFadden ET, Carbone PP: Toxicity and response criteria of the Eastern Cooperative Oncology Group. Am J Clin Oncol 5:649-655,1982

32. Paul T, Challa S, Tandon A, Panigrahi M, Purohit AK: Primary central nervous system lymphomas: Indian experience, and review of literature. Indian J Cancer 45(3):112-118, 2008

33. Powari M, Radotra B, Das A, Banerjee AK: A study of primary central nervous system lymphoma in Northern India. Surg Neurol 57(2):113-116,2002
34. Rosenthal MA, Sheridan WP,Green MD, Liew K, Fox RM: Primary cerebral lymphoma: An argument for the use of adjunctive systemic chemotherapy. Aust N Z J Surg 63:30-32,1993

35. Roser F, Saini M, Meliss R, Ostertag H, Samii M, Bellinzona M: Apoptosis, vascularity and proliferation in primary central nervous system lymphomas (PCNSL) a histopathological study. Surg Neurol 62(5):393-399,2004

36. Rumana M, Khursheed N, Altaf Kirmani, Altaf Ramzan, Rayees Ahmad, Parveen Shah, Wani MA, Khalil MB: Clinicopathologic Characteristics of Brain Gliomas: Experience From Culturally and Geographically Distinct Kashmir Valley. Neurosurgery Quarterly 19(4):288-294, 2009

37. Sarkar C, Sharma MC, Deb P, Singh R, Santosh V, Shankar SK: Primary central nervous system lymphoma: $A$ hospital based study of incidence and clinicopathological features from India (1980-2003). J Neurooncol 71(2):199-204,2005

38. Su IC, Lien HC, Chen CM: Primary brain T-cell lymphoma after kidney transplantation: A case report. Surg Neurol 66 Suppl 2:S60-63,2006

39. Werner MH, Phuphanich S, Lyman GH: The increasing incidence of malignant gliomas and primary central nervous system lymphoma in the elderly. Cancer 76(9):1634-1642,1995 